\title{
CXCR3 wt Allele
}

National Cancer Institute

\section{Source}

National Cancer Institute. CXCR3 wt Allele. NCI Thesaurus. Code C51334.

Human CXCR3 wild-type allele is located within Xq13 and is approximately $3 \mathrm{~kb}$ in length.

This allele, which encodes $C-X-C$ chemokine receptor type 3 protein, is involved in the recruitment of inflammatory cells and signal transduction. 